\title{
NEW YTTRIA PLASTERS
}
C. E. Holcombe
C. C. Edwards
D. A. Carpenter

\section{OAK RIDGE Y-12 PLANT} OAK RIDGE. TENNESSEE 


\section{DISCLAIMER}

This report was prepared as an account of work sponsored by an agency of the United States Government. Neither the United States Government nor any agency Thereof, nor any of their employees, makes any warranty, express or implied, or assumes any legal liability or responsibility for the accuracy, completeness, or usefulness of any information, apparatus, product, or process disclosed, or represents that its use would not infringe privately owned rights. Reference herein to any specific commercial product, process, or service by trade name, trademark, manufacturer, or otherwise does not necessarily constitute or imply its endorsement, recommendation, or favoring by the United States Government or any agency thereof. The views and opinions of authors expressed herein do not necessarily state or reflect those of the United States Government or any agency thereof. 


\section{DISCLAIMER}

Portions of this document may be illegible in electronic image products. Images are produced from the best available original document. 
Reference to a company or product name does not imply approval or recommendation of the product by Union Carbide Corporation or the Department of Energy to the exclusion of others that may meet specifications.

Printed in the United States of America. Available from National Technical Information Service

U.S. Department of Commerce

5285 Port Royal Road, Springfield, Virginia 22161

Price: Printed Copy $\$ 4.00 ;$ Microfiche $\$ 3.00$

This report was prepared as an account of work sponsored by an agency of the United States Government. Neither the United States Government nor any agency thereof, nor any of their employees, nor any of their contractors, subcontractors, or their employees, makes any warranty, express or implied, nor assumes any legal liability or responsibility for any third party's use or the results of such use of any information, apparatus, product or process disclosed in this report, nor represents that its use by such third party would not infringe privately owned rights. 
Distribution Category: UC-25

\title{
NEW YTTRIA PLASTERS
}

\author{
C. E. Holcombe \\ Process Engineering Department \\ C. C. Edwards \\ Chemical and Plastics Department \\ D. A. Carpenter \\ Instrumentation and Characterization Department \\ Y-12 Development Division
}

\begin{abstract}
This report was prepared as an account of work sponsored by the United States Govemment. Neither the

United States nor the United States Department of

Energy, nor any of their employees, nor any of their

contractors, subcontractors, or their employees, makes

any warranty, express or implied, or assumes any legal

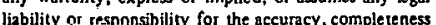

lizbility or respnnsibility for the accuracy, completeness

or usefulness of any information, apparatus, product or

process disclosed, or represents
\end{abstract}

Oak Ridge $Y-12$ Plant

P. O. Box Y, Oak Ridge, Tennessee 37830

Prepared for the Department of Energy

Under US Government Contract W-7405-eng-26 
ABSTRACT

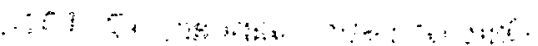

The physical and chemical properties of a new, sinterable yttria $\left(\mathrm{Y}_{2} \mathrm{O}_{3}\right)$ plaster, formed in the yttria/acid/water (dilute-acids) system, were determined. The binder phases responsible for plaster formation were of the form $\mathrm{Y}_{2}(\mathrm{OH})_{6}-\mathrm{m} \cdot \mathrm{X}_{\mathrm{m}} \cdot \mathrm{nH}_{2} \mathrm{O}$, with $\mathrm{m}=n \sim 1$ and $X$ represents either $\mathrm{Cl}^{-}$. or $\mathrm{NO}_{3}^{-}$. Binder-phase decomposition behavior was studied by thermal analysis. 


\section{CONTENTS}

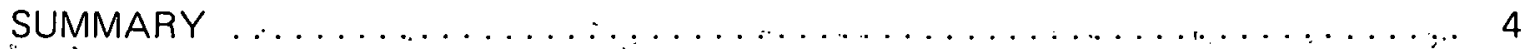

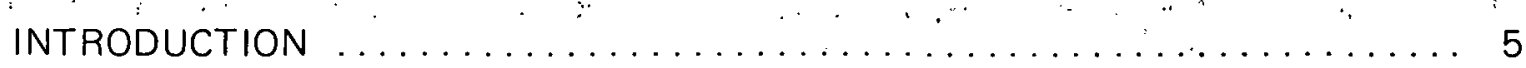

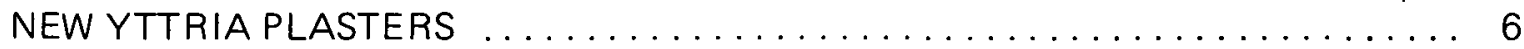

Experimental Procedure . . . . ............................ 6

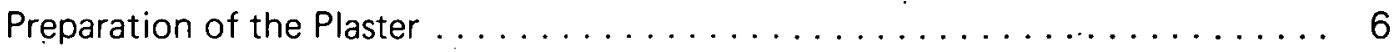

Preparation of Yttrium Hydroxynitrate and Hydroxychloride Hydrates . . . . . 7

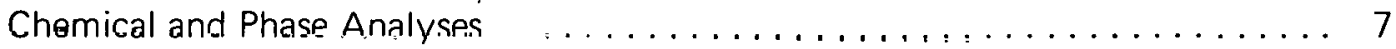

Physical Characterization . . . . . . . . . . . . . . . . . 8

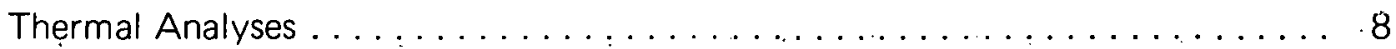

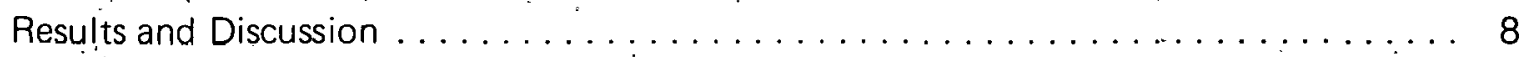

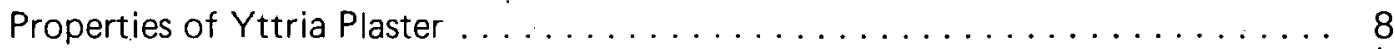

Possible Mechanism of Plaster Formation . . . . . . . . . . . . . . . . 15

Materials Incorporation into Yttria Plaster . . . . . . . . . . . . . . 16

Yttria Plaster Sinterability Studies . . . . . . . . . . . . . . . . 16

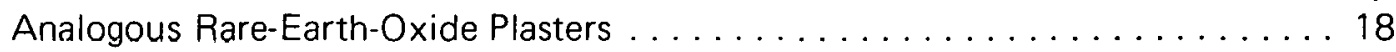

Conclusions ................................... 18

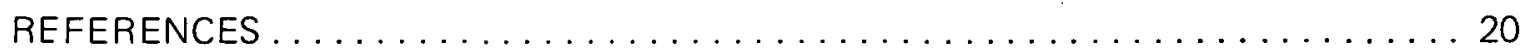

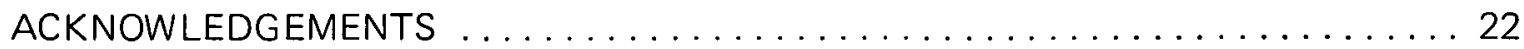




\section{SUMMARY}

A new, sinterable yttria $\left(\mathrm{Y}_{2} \mathrm{O}_{3}\right)$ plaster was developed. The properties of this plaster depend on: (1) starting-powder characteristics, (2) type and concentration of the acid used for the liquid phase, and (3) the liquid-to-powder (L/P) ratios. Physical and chemical properties of the yttria plaster were investigated.

Plasters formed in the yttria/acid/water (dilute-acids) system were determined to consist mostly of needle (or plate)-shaped hydroxysalt binder phases analogous to precipitates in the $\mathrm{YX}_{3}$ /sodium hydroxide/water system. (where $\mathrm{X}$ represents either $\mathrm{Cl}^{-}$or $\mathrm{NO}_{3}{ }^{-}$). The binder phases were shown to be of the form $\mathrm{Y}_{2}(\mathrm{OH})_{6}-\mathrm{m} \mathrm{X}_{m} \cdot \mathrm{nH}_{2} \mathrm{O}$, where $m$ and $n$ generally equal one.

The decomposition behavior on heating yttria plasters was studied by thermal analyses. The nitric acid-produced plasters decomposed to yttria below $600^{\circ} \mathrm{C}$ in argon; the hydrochloric acid-produced plasters decomposed to yttria by $1520^{\circ} \mathrm{C}$ in argon or by $1100^{\circ} \mathrm{C}$ in air.

Examination of scandium oxide and the rare-earth oxides showed that several exhibited a plaster-forming behavior similar to yttria. 


\section{INTRODUCTION}

While investigating the use of yttria coatings for the graphite crucibles used in uranium melting operations at the Oak Ridge Y-12 Plant, (a) dilute nitric acid solutions were used with yttria powder in an attempt to form a stable suspension that was free of any carbon-containing suspension agent. A material resembling plaster of paris resulted. Because of the potential use of yttria cementitious phases with reactive materials (such as lithium, lithium hydride, nickel, titanium, zirconium, and uranium) with which yttria is thermodynamically stable, this investigation was undertaken. The first part of the study was directed toward yttria plaster, a rapidly formed, porous material useable for coatings, molds, microfilters, and castable thermal and electrical insulators.

Although there is considerable information in the literature on the mechanism and kinetics of formation of calcium sulfate hemihydrate plasters (ie, by Schiller, ${ }^{1}$ Taplin, $^{2}$ Ridge and Surkevicius, ${ }^{3}$ Ridge and King, ${ }^{4}$ Jacobs, ${ }^{5}$ and Lambe and Ofutt $\left.{ }^{6}\right)$, there is apparently.no report of any other analogous hydration system yielding a plaster. The recent binder classification scheme proposed by Sychev 7,8 considers gypsum plaster, and portland and calcium aluminate cements as hydration materials where crystallization of a sparingly soluble ór insoluble compound (new phase) results from a supersaturated solution. Considering this broad class of binder (chemical interaction to form a new phase), a subgroup consists of cements formed from an acid/base interaction, such as the phosphate cements studied by Kingery 9,10 and a wide variety of acid/oxide reaction cements reported by Federov. ${ }^{11}$ The plaster prepared from yttria and dilute acids appears to be a new hydration product that has a closer association to gypsum plaster than to cements ordinarily formed from an acid/oxide reaction.

(a) Operated by the Union Carbide Corporation's Nuclear Division for the Department of Energy. 


\section{NEW YTTRIA PLASTERS}

\section{EXPERIMENTAL PROCEDURE}

\section{Preparation of the Plaster}

A plaster of yttria was produced by: (1) mixing yttria powder(b) (nominally $>99.9$ wt \% pure) with a dilute acid solution and stirring until a fluid slurry or suspension resulted; (2) casting the slurry into a mold or around a mandrel (eg, fluorocarbon-coated metal or glass); and (3) allowing for an incubation period wherein the material "sets" [about 5 to.30 minutes, depending primarily on the particle size, acid concentration, and liquid-to-powder (L/P) ratio].(C) The setting was exothermic. After setting, the as-formed plaster was thoroughly dried in air from 20 to $60^{\circ}$. C before examination.

The yttria plaster was prepared from a starting powder with mean particle diameters ranging from 0.05 to $25 \mu \mathrm{m}$. The optimum material had agglomerates, (d) with a mean overall diameter of $3.5 \mu \mathrm{m}$, consisting of particles with a mean diameter of $0.06 \mu \mathrm{m}$. $(\mathrm{e})$ In general, larger particle sizes resulted in a faster setting time, but the plaster had less strength.

Nitric and hydrochloric acid solutions allowed rapid (5 to 30 minute) formation of a coherent plaster. Other acid solutions (ie, $\mathrm{HF}, \mathrm{HBr}, \mathrm{HI}, \mathrm{HClO}_{4}, \mathrm{HCOOH}, \mathrm{CH}_{3} \mathrm{COOH}$, $\mathrm{H}_{2} \mathrm{SO}_{4}, \mathrm{H}_{3} \mathrm{PO}_{4}$, and $\mathrm{H}_{2} \mathrm{CO}_{3}$ ) caused a slower setting time, a weaker plaster, or no evidence of hydration bonding (as in $\mathrm{H}_{2} \mathrm{CO}_{3}$ ).

Nitric acid concentrations from 0.61 to $3.95 \underline{M}$ were used, with 1.44 to $3.16 \underline{M}$ being preferred for rapid plaster formation. Concentrations greater than $3.16 \underline{M}$ were unmanageable, causing instant and nonuniform hardening before mixing could be completed; whereas, concentrations less than $1.44 \mathrm{M}$ required long times (greater than one hour) to cause hardening of the plaster. For hydrochloric acid solutions, cuncentrations of 1.34 to $2.42 \underline{M}$ were used to prepare the plasters.

Liquid-to-powder ratios from 0.56 to 1.44 were used, with the lower value being limited by the requirement of having a workable mix. When the L/P ratio exceeds 1.44 , plaster will form under the excess liquid. The lower L/P ratios cause shorter setting times (ie, 2 - 5 minutes). An L/P ratio of 1.0 was generally used.

An examination was made of the effects on plaster formation of adding different materials to yttria. The reactivity of yttria plaster was also investigated, as was its sinterability. A

(b) A product of the Michigan Chemical Corporation, St. Louis, Michigan.

(c) L/P represents the ratio of the liquid (dilute acid) volume in milliliters to the powder weight in grams.

(d) Agglomerate size by. Micromerograph.

(e) Particle size by electron microscope. 
flowing argon $(\sim 30 \mathrm{l} / \mathrm{min})$ atmosphere was used in a resistance-heated graphite furnace (ASTRO Model 1000A) with a platinum sample support. Temperature was controlled with a Research, Inc Data Trak card programmer using a Pt/Pt-10 Rh thermocouple.

Because of the general chemical similarity of yttrium with scandium and the rare earths, attempts were made to form plasters with each of their oxides (nominally $>99.9 \%$ pure), excluding promethium, using nitric or hydrochloric acid in the same manner as with the yttria plaster.

\section{Preparation of Yttrium Hydroxynitrate and Hydroxychloride Hydrates}

For comparison with yttria plasters [from the $\mathrm{Y}_{2} \mathrm{O}_{3} / \mathrm{HNO}_{3}$ (or $\mathrm{HCl}$ )/ $\mathrm{H}_{2} \mathrm{O}$ system], precipitates in the $\mathrm{Y}\left(\mathrm{NO}_{3}\right)_{3} / \mathrm{NaOH} / \mathrm{H}_{2} \mathrm{O}$ and $\mathrm{YCl} 3 / \mathrm{NaOH} / \mathrm{H}_{2} \mathrm{O}$ systems were produced. The hydrated salts $\left[\mathrm{Y}\left(\mathrm{NO}_{3}\right) \cdot \mathrm{nH}_{2} \mathrm{O}\right.$ and $\mathrm{YCl} 3 \cdot \mathrm{nH}_{2} \mathrm{O}$ (where $\left.\left.\mathrm{n} \approx 6\right)\right]$ were prepared by completely dissolving yttria in concentrated nitric $(7.9 \mathrm{M})$ or hydrochloric $(6.0 \mathrm{M})$ acid solutions, followed by evaporation to dryness. To a dilute solution of the yttrium salt, a dilute solution of sodium hydroxide was added with the $\mathrm{OH}^{-}-$to- $\mathrm{Y}^{+3}$ ratio ranging from 1 to 2 . The precipitate was heated to $60^{\circ} \mathrm{C}$ for 15 minutes while stirring before being washed and filtered to remove sodium salt. The precipitate was then dried at $60^{\circ} \mathrm{C}$ for 24 hours and examined.

\section{Chemical and Phase Analyses}

The nitric and hydrochloric acid-produced plasters, along with the precipitated hydroxysalt phases, were analyzed for yttrium (X-ray fluorescence, $\pm 0.01 \%(f)$ ); oxygen (neutron activation, $\pm 0.1 \%$ ), and hydrogen, nitrogen, and chlorine : (standard chemical analyses, $\pm 0.2 \%)$. Dual aliquots were taken. Densities of the precipitated phases were measured by toluene displacement.

Each of these materials was examined by X-ray diffraction (XRD) techniques, using a 114.6-mm Debye-Scherrer camera with nickel-filtered $\mathrm{Cu} \mathrm{K \alpha}$ radiation. In addition, samples were step scanned, using a Siemens diffractometer equipped with a graphite monochromator and srintillation detestor combined with a single-chaninel pulse height analyzer. A 1/2-degree entrance aperture slit was used so that the sample would intercept the entire beam ( $\mathrm{Cu} \mathrm{K} \alpha$ radiation) at low $2 \theta$ values.

For yttria plasters $\left(\mathrm{HNO}_{3}\right.$ and $\mathrm{HCl}$ produced), a quantitative phase analysis of yttria was carried out by diffractometry, using the "internal-standard technique. 12,13 Linde $A$ corundum $\left(\mathrm{Al}_{2}, \mathrm{O}_{3}\right)$ was used as the internal standard. The standard curve was determined by measuring the intensity ratio of the (400) yttria peak to the (012) alumina peak of a 1-to-1 (by weight) mixture of yttria and alumina. The intensity ratio for this mixture was $3.18 \pm 0.04$ (95\% confidence interval, as determined by repetitive runs).

(f) Typical standard deviation from reported values. 


\section{Physical Characterization}

Each of the plasters formed was examined by scanning electron microscopy to determine their morphology. The nitric and hydrochloric acid-produced yttria plasters were examined by standard mercury intrusion porosimeter techniques (as given by Drake and Ritter $\left.{ }^{14}\right)(\mathrm{g}$ )

Hardness of the nitric acid-produced yttria plaster ( $L / P=0.56$, using $2.63 \underline{M} \mathrm{HNO}_{3}$ ) and technical-grade plaster of paris [water-to-powder ratio $(W / P)=0.7$ ] casts was determined using the Rockwell $Y(1.27-\mathrm{cm}$-diameter) ball penetrator with a $15-\mathrm{kg}$ load. The average of 14 measurements is reported with the standard deviation.

\section{Thermal Analyses}

Simultaneous differential-thermal-analysis (DTA)/thermal-gravimetric-analysis $(T G A)^{(h)}$ data were undertaken for both the nitric and hydrochloric acid-produced plasters and for the precipitated hydroxysalt phases. These studies were in a flowing $(4$ to $6 \mathrm{l} / \mathrm{h})$ argon or air atmosphere with alumina as the reference material and a platinum crucible. Temperature was measured with a Pt/Pt-10 Rh thermocouple, and a $60^{\circ} \mathrm{C} / \mathrm{min}$ heating rate was used.

Complementing the DTA/TGA studies, thermogravimetric quadrupole mass spectrographic (TG-quad) analyses were conducted [vacuum $<10^{-4}$ torr $\left(<1.33 \times 10^{-2} \mathrm{~Pa}\right)$ ] for the plasters in order to determine the evolved gaseous species.

\section{RESULTS AND DISCUSSION}

\section{Properties of Yttria Plaster}

The plasters produced by the procedure just described have(i) porosities in the range of 50 to $65 \%$, average pore diameters of 0.5 to $2 \mu \mathrm{m}$, bulk densities of 1.1 to $1.6 \mathrm{~g} / \mathrm{cm}^{3}$, and apparent specific gravities of 2.7 to 3.3. Essentially all of the plasters had pore diameters less than $10 \mu \mathrm{rri}$.

Examination of yttria plaster by the scanning electron microscope (SEM) revealed that the material is a mass of tangled needle and plate-like crystals having random orientation, yielding a continuously connected network of small pores. These features are seen in Figure 1 for nitric acid-produced plaster (where some unreacted yttria powder is visible),

(g) Described completely in Aminco Digital Readout Porosimeter, Catalog 5-7121A, Instruction 907-C, published by the American Instrument Co, Inc, February 1968.

(h) Thermoanalyzer Model TA1, Mettler Equipment Corporation, Princeton, NJ.

(i) Data from porosimetry. 


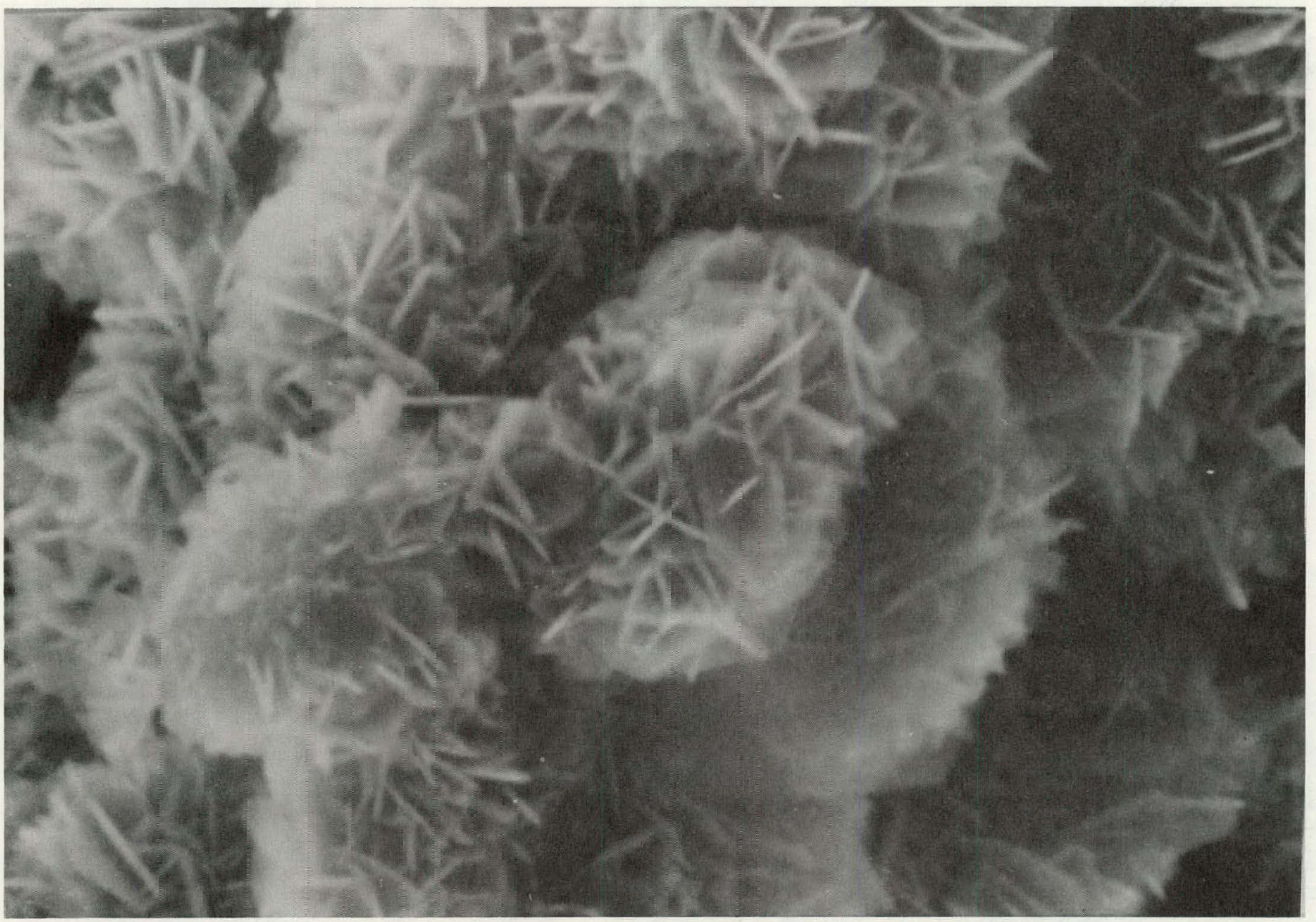

Figure 1. AS-FORMED YTTRIA PLASTER. $-/ \mathrm{P}=1.44$, Using $3.16 \underline{\mathrm{M}} \mathrm{HNO}_{3}$; All Figure Widths of Photomicrographs Represent $\sim 11 \mu \mathrm{m}$ ) 
resembling a matrix of cotton. The hydrochloric acid-produced plaster has an appearance that is similar to the nitric acid-produced material except that the needles (or plates) are smaller for the former $(0.2-0.5 \mu \mathrm{m} \mathrm{Lx} \sim 0.05 \mu \mathrm{mW})$ than for the latter $(0.2-1.0 \mu \mathrm{m}$ $\mathrm{L} \times 0.05-0.1 \mu \mathrm{m} \mathrm{W})$.

Because the appearance of yttria plaster is equivalent to plaster of paris, a comparison between the Rockwell hardness number ( $\mathrm{RHN}$ ) values of nitric acid-produced yttria plaster and plaster of paris with similar porosities (50\% for the former and $53 \%$ for the latter) was undertaken to further point out their similarities. The yttria plaster had a RHN value of $103 \pm 5$ and the gypsum plaster a value of $82 \pm 5$. The hardness difference $(25 \%)$ is related to the bonding that takes place between the plaster needles and to the needle size. (Note that, from SEM observation, the needles of nitric acid-produced yttria plaster are about a tenth the size of the gypsum needles.)

Initial XRD analysis of yttria plaster produced from dilute nitric acid or hydrochloric acid showed the presence of yttria (as the major phase) along with an unidentified(j) phase. A review of the literature on hydroxysalts revealed that yttrium "basic" salts of approximate formula $\mathrm{Y}_{2}(\mathrm{OH})_{5} \mathrm{X} \cdot \mathrm{nH}_{2} \mathrm{O}$ (where $X=\mathrm{NO}_{3}{ }^{-}$or $\mathrm{Cl}^{-}$and $\mathrm{n}=1$ - 2) are precipitated from $\mathrm{Y}$ salt/alkali hydroxide/water systems $15-19$ and that, generally, dehydrated phases of the same stoichiometry result from hydrothermal ( $\sim 400^{\circ} \mathrm{C}, \sim 1200 \mathrm{~atm}$ ) conditions. 20 - 22 The $X R D$ data available 23 for the hydrothermally prepared phases (one of which corresponded with the formula just given) did not match the diffraction patterns from the yttria plasters. Samples were prepared, since the precipitates were the only reported nitrate and chloride hydroxysalts for which XRD data were not available. The XRD observed patterns of the precipitates account for the unidentified XRD patterns in the plasters.

Table 1 lists the results of the analyses of the yttria plaster and precipitated phases. It is apparent that the hydration binder phase is of the general form $\mathrm{Y}_{2}(\mathrm{OH})_{6-m} X_{m} \cdot \mathrm{nH}_{2} \mathrm{O}$ (where $\mathrm{m} \approx 1$ and $\mathrm{n} \approx 1$ for the $\mathrm{HNO}_{3}{ }^{-}$produced plaster and for the precipitated phase). $\mathrm{A}$ cyclic formation technique (acid reaction, drying, and grinding for each cycle) was attempted with both nitric acid and hydrochloric acid to eliminate free yttria; the former resulted in the appearance of unidentified XRD lines in addition to the normal-binder-phase XRD pattern (after 5 cycles with $1.76 \mathrm{M} \mathrm{HNO}_{3}, \mathrm{~L} / \mathrm{P}=1.0$ ), although the latter caused no change in the XRD pattern of the hydroxychloride binder phase (after 5 cycles with $1.34 \mathrm{M}$ $\mathrm{HCl}, L / P=1.0)$. The hydroxychloride binder thus appears to have a wider homogeneity range than does the hydroxynitrate binder. Chemical analysis of the hydroxychloride binder from cyclic formation revealed essentially $\mathrm{Y}(\mathrm{OH})_{2} \mathrm{Cl}$, (see Table 1) which has been previously reported. 24 - 26 However, the XRD patterns of the chloride-containing materials listed in Table 1 were the same. It appears that $0.75 \leqslant m \leqslant 2.0$ and $0 \leqslant n \leqslant 1$ represent the

(j) From data available in the Powder Diffraction File, Joint Committee on Powder Diffraction Standards, 1601 Park Lane, Swarthmore, PA 19081. 
Table 1

ANALYSES OF YTTTRIUM HYDROXYNITRATE AND HYDROXYCHLORIDE PHASES

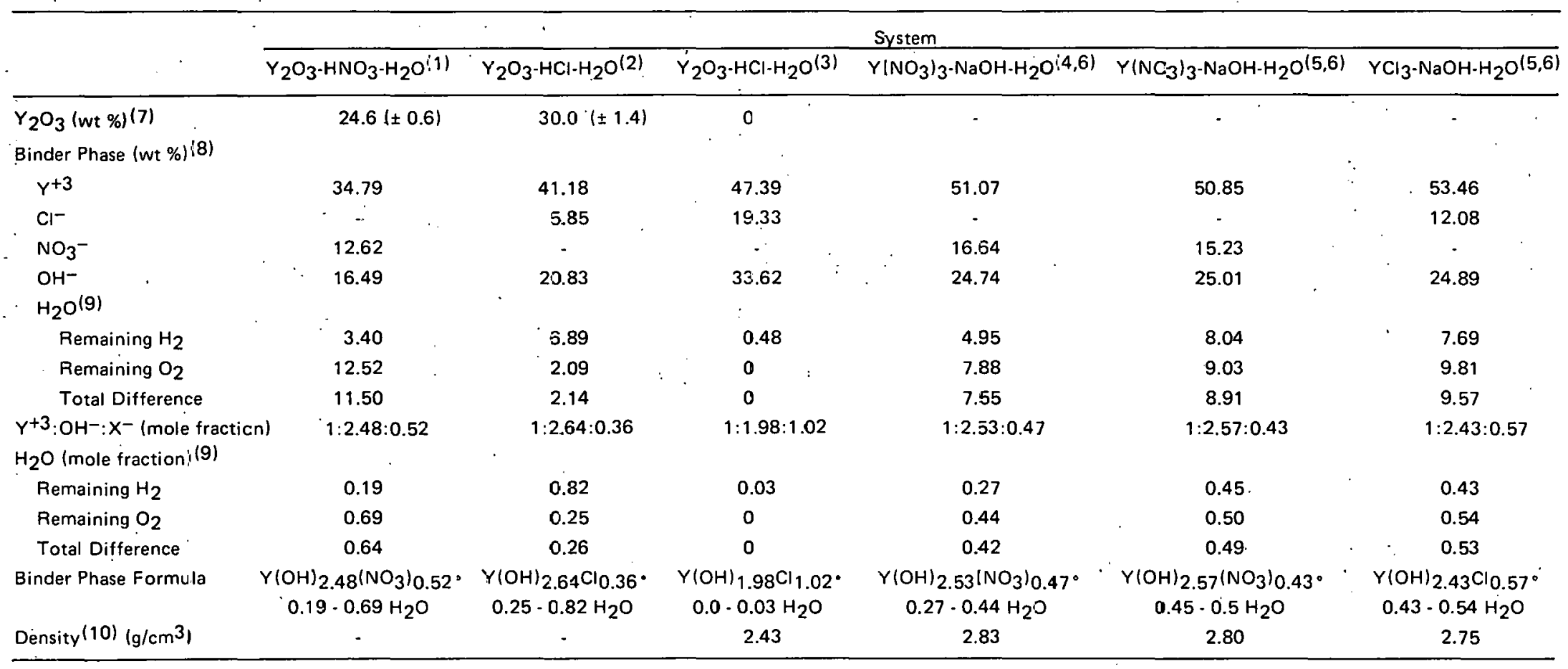

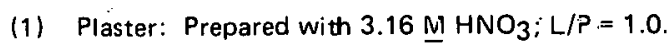

(2) Plaster: Prepared with $2.42 \mathrm{M} \mathrm{HCl} ; \mathrm{L} / \mathrm{P}=\mathbf{1 . 0}$.

(3) Plaster: Prepared with $1.34 \mathrm{M} \mathrm{HCl}$; reacted, Jried, and ground 5 cycles; $L / P={ }_{i} 1.0$, each cycle.

(4) Precipitate: Ratio $\left(\mathrm{C}^{-} \mathrm{H}^{-}: \mathrm{Y}^{+3}\right)=1.0$

(5) Precipitate: Ratio $\left(\mathrm{CH}^{-}: \mathrm{Y}^{+3}\right)=2.0$

(6) Precipitate: Hydroxide solution added to nitrate solution.

(7) Determined by XRD quantitative phase analyses; $95 \%$ corfidence interval is given in parentheses.

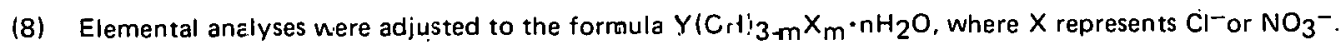

(9) Calculated from remaining hydrogen, remaining oxygen; ar from the total difference necessary for $100 \%$ when summing constituents.

(10) Determined by toluene displacement. 
range over which the hydroxychloride binder phase may retain the same crystal structure. It should be also noted that drying these materials $\left(20\right.$ to $60^{\circ} \mathrm{C}$ ) appears to cause no distinct changes in their XRD patterns.

The XRD patterns of the precipitated hydroxysalt binder phases are reported in Tables 2 (nitrate) and 3 (chloride). These XRD patterns are suitable for identification of these phases in yttria plasters. For the nitric acid and hydrochloric acid-produced plasters in Table 1 (single cycle), the presence of a large amount of yttria (as previously noted) was indicated. Ratio of the heights of

Table 3

$X$-RAY DIFFRACTION PATTERN OF

$\mathrm{Y}_{2}(\mathrm{OH})_{4.86} \mathrm{Cl} 1.14 \cdot 1.07 \mathrm{H}_{2} \mathrm{O}$ BINDER PHASE

\begin{tabular}{|c|c|c|c|}
\hline $\begin{array}{c}\text { d-Spacings (1) } \\
(\AA)\end{array}$ & $1 / I_{100^{(2)}}$ & $\begin{array}{l}\text { d-Spacings } \\
(\AA)\end{array}$ & $1 / I_{100}(2)$ \\
\hline 8.46 & 100 & 1.888 & 2 \\
\hline 7.00 & 1 & 1.859 & 3 \\
\hline 5.00 & 6 & 1.819 & 9 \\
\hline 4.23 & 15 & 1.784 & 8 \\
\hline 4.00 & 3 & 1.749 & 4 \\
\hline 3.77 & 5 & 1.670 & 5 \\
\hline 3.56 & 2 & 1.621 & $<1$ \\
\hline 3.49 & 4 & 1.582 & 2 \\
\hline 3.33 & 3 & 1.556 & 4 \\
\hline 3.16 & 1 & 1.531 & 4 \\
\hline 3.10 & 28 & $1.4 \% 9$ & 3 \\
\hline 2.96 & 12 & 1.461 & 1 \\
\hline 2.92 & 14 & 1.421 & $<1$ \\
\hline 2.81 & 1 & 1.371 & 2 \\
\hline 2.75 & $<$ & 1.296 & 1 \\
\hline 2.59 & 3 & 1.252 & $<1$ \\
\hline 2.50 & 8 & 1.236 & $<1$ \\
\hline 2.33 & 6 & 1.220 & $<1$ \\
\hline 2.29 & 6 & 1.187 & 2 \\
\hline 2.23 & 5 & 1.174 & 1 \\
\hline 2.17 & 5 & 1.160 & 1 \\
\hline 2.08 & 4 & 1.141 & $<1$ \\
\hline 2.05 & 3 & 1.128 & $<1$ \\
\hline 2.03 & 4 & 1.112 & 1 \\
\hline 2.01 & 6 & & \\
\hline
\end{tabular}

(1) Precipitated by the addition of $\mathrm{NaOH}$ to a $\mathrm{YCl}_{3}$ solution (ratio of $\mathrm{OH}^{-}: \mathrm{Y}^{+3}=2.0$ ); formula baser on chemical analysis, with the water content representing the average calculated from remaining oxygen or by difference (see Table 1).

(2) Peak height intensities, diffractometer, $\mathrm{Cu} \mathrm{K \alpha}$ radiation.
Table 2

$X$-RAY DIFFRACTION PATTERN OF $\mathrm{Y}_{2}(\mathrm{OH})_{5.14}\left(\mathrm{NO}_{3}\right)_{0.86} \cdot 0.99 \mathrm{H}_{2} \mathrm{O}$ BINDER PHASE

\begin{tabular}{|c|c|}
\hline $\begin{array}{c}\text { d-Spacings (1) } \\
(\AA)\end{array}$ & $1 / I_{100}(2)$ \\
\hline 9.22 & 100 \\
\hline 4.60 & 32 \\
\hline 3.19 & 5 \\
\hline 3.12 & 20 \\
\hline 2.53 & $<1$ \\
\hline 2.40 & $<$ \\
\hline 2.23 & $<1$ \\
\hline 2.04 & $<1$ \\
\hline 1.824 & 3 \\
\hline 1.781 & 3 \\
\hline 1.590 & 1 \\
\hline 1.553 & 2 \\
\hline 1.252 & $<1$ \\
\hline 1.166 & $<1$ \\
\hline
\end{tabular}

(1) Compound was precipitated by the addition of $\mathrm{NaOH}$ to a $\mathrm{Y}\left(\mathrm{NO}_{3}\right)_{3}$ solution (ratio of $\mathrm{OH}^{-}$$Y^{+3}=2.0$ ); formula based on chemical analysis, with the water content representing the average calculated from remaining oxygen or by difference (see Table 1).

(2) Peak height intensities, diffractometer, $\mathrm{Cu} K \alpha$ iadiatiun.

the most interise pedks $(9.22 \AA$ peak of hydroxynitrate to $3.07 \AA$ peak of $y$ ttria) is 0.36 for a plaster which contained only $24.6 \mathrm{wt} \%$ yttria. Similarly, for the hydrochloric acidproduced plaster, the ratio (8.46 $\AA$ peak of hydroxychloride to $3.07 \AA$ peak of yttria) is 0.37 for a plaster which contained $30.0 \mathrm{wt} \%$. $y$ ttria. These observations are indicative of the much lower diffracting power of these hydroxysalts compared to yttria. This difference might be expected since the hydroxysalt binder phases contain a high percentage "of lowatomic-number atoms and have relatively low densities.

Similarity of the XRD patterns of the hydroxysalt phases can be seen in Figure 2 . 


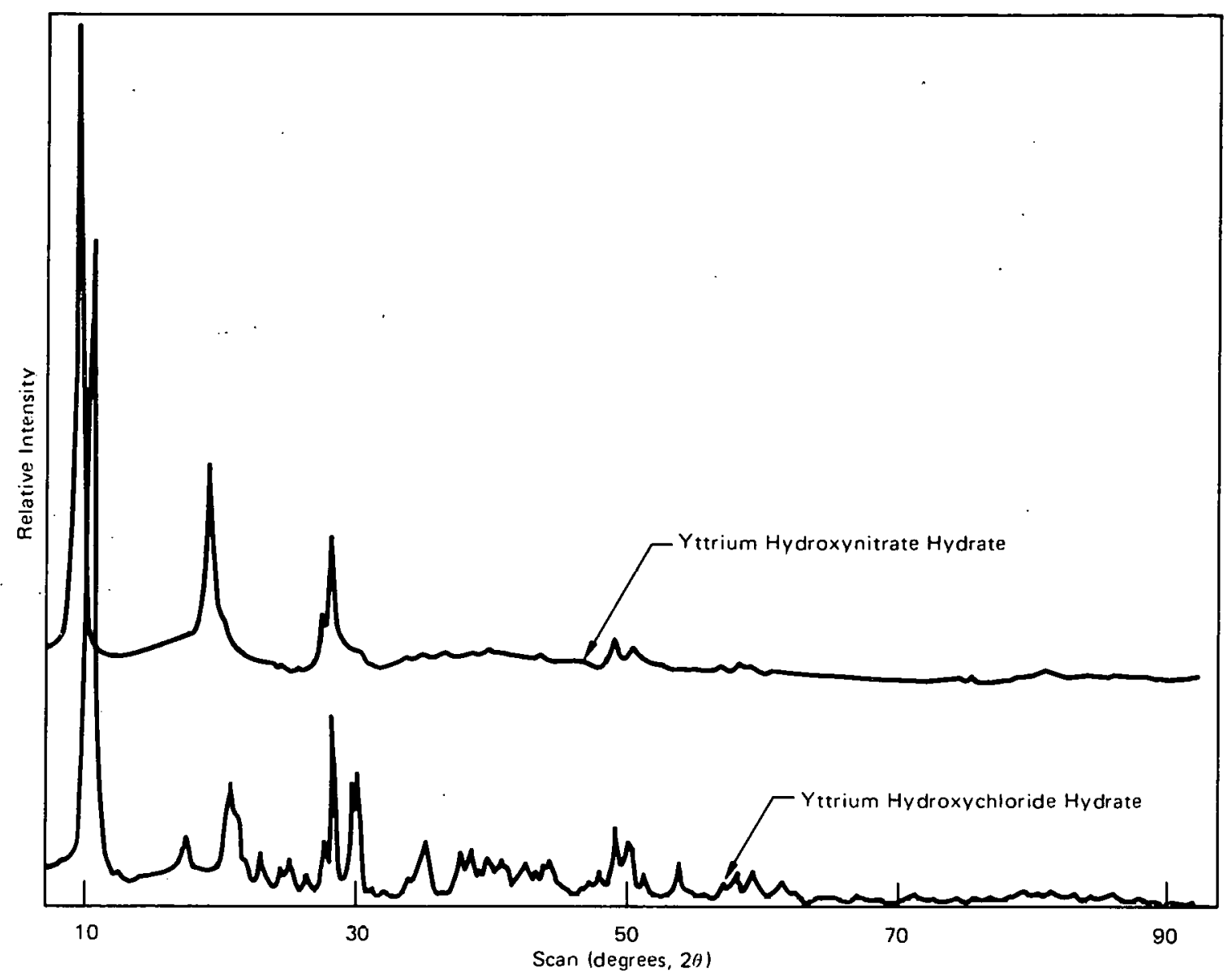

Figure 2. X-RAY DIFFRACTION SCANS FOR TWO YTTRIUM BINDERS.

The close correspondence of the formulat and XRD patterns of the hydrated hydroxynitrate and hydroxychloride binder phases is in accord with the observation of other workers 21,22 for phases of similar composition (except dehydrated). The crystal structures of the hydrated hydroxynitrate and hydroxychloride hinder phases are probably closely related. Attempts at indexing the XRD patterns or growing single crystals have been unsuccessful.

Thermal analyses of yttria plasters and precipitated hydroxysalt phases matched. DTA/TGA curves for the precipitated phases are given in Figure 3. For nitrate materials, TG-quad indicated that the nitrogen components (such as $\mathrm{N}_{2} \mathrm{O}, \mathrm{NO}$, and $\mathrm{NO}_{2}$ ) are cvolvod above $3500 \mathrm{C}_{-}$, indirating that thermal effects below that temperature are caused by dehydration. The mode of decomposition of the nitrate binder is indicated in Graph $b$ of Figure 3, where the material loses water to form $\mathrm{Y}_{2}(\mathrm{OH})_{5.14}\left(\mathrm{NO}_{3}\right)_{0.86}$ in the temperalure range from 100 to $200^{\circ} \mathrm{C}$. From this point, the thermal desomposition is essentially analogous to that reported ${ }^{20}$ for $\mathrm{La}_{2}(\mathrm{OH})_{5.1}\left(\mathrm{NO}_{3}\right)_{0.9}$, with the endothermal decomposition (DTA peak at $337{ }^{\circ} \mathrm{C}$ ) leading to $\mathrm{Y}_{2} \mathrm{O}_{2}(\mathrm{OH})_{1.14}\left(\mathrm{NO}_{3}\right)_{0.86}$ which then decomposes endothermally (DTA peak at $543^{\circ} \mathrm{C}$ ) to ytria. Stepwise decompusition 

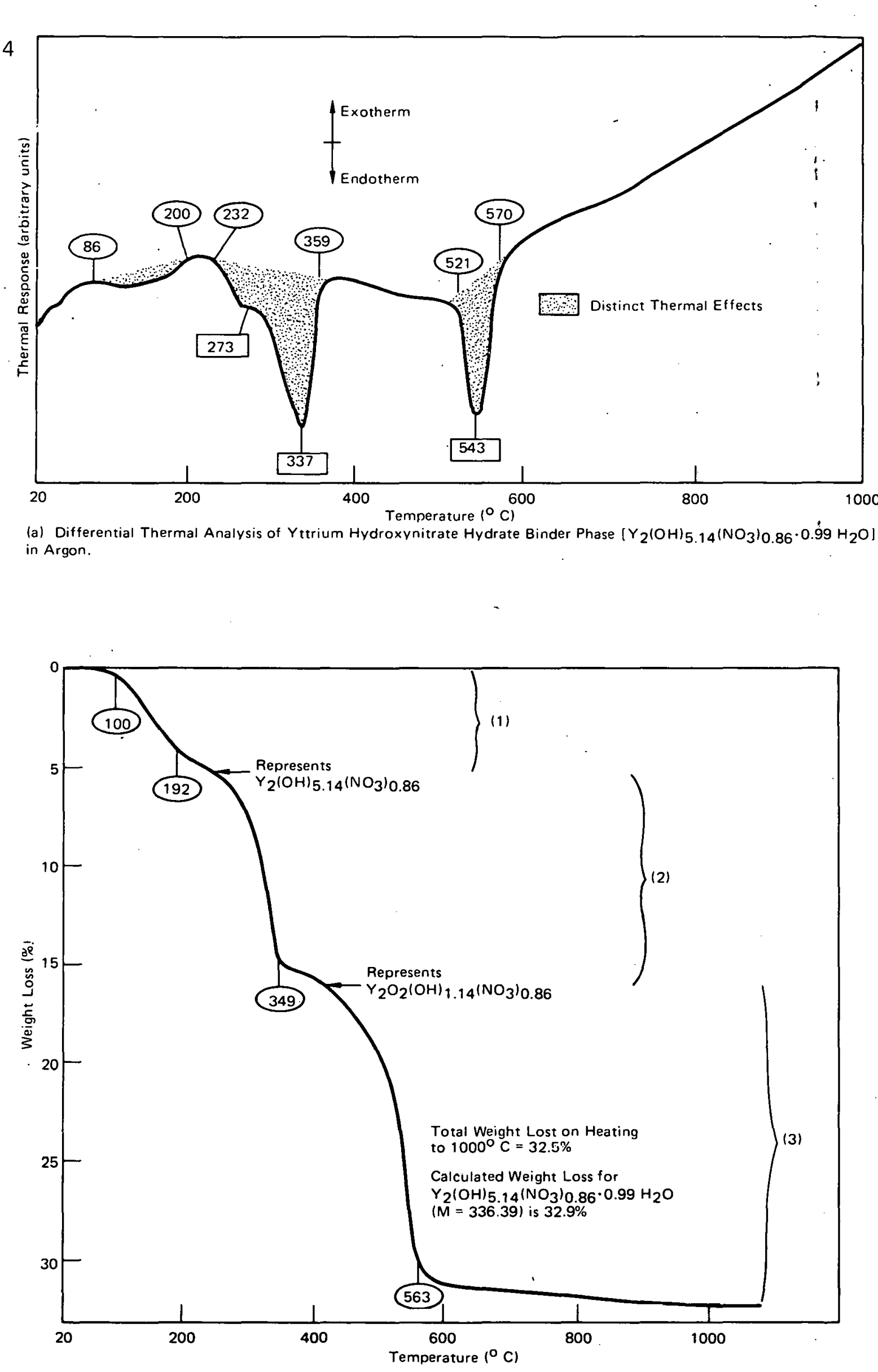

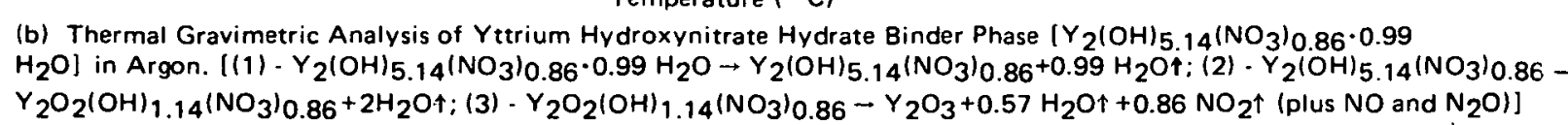
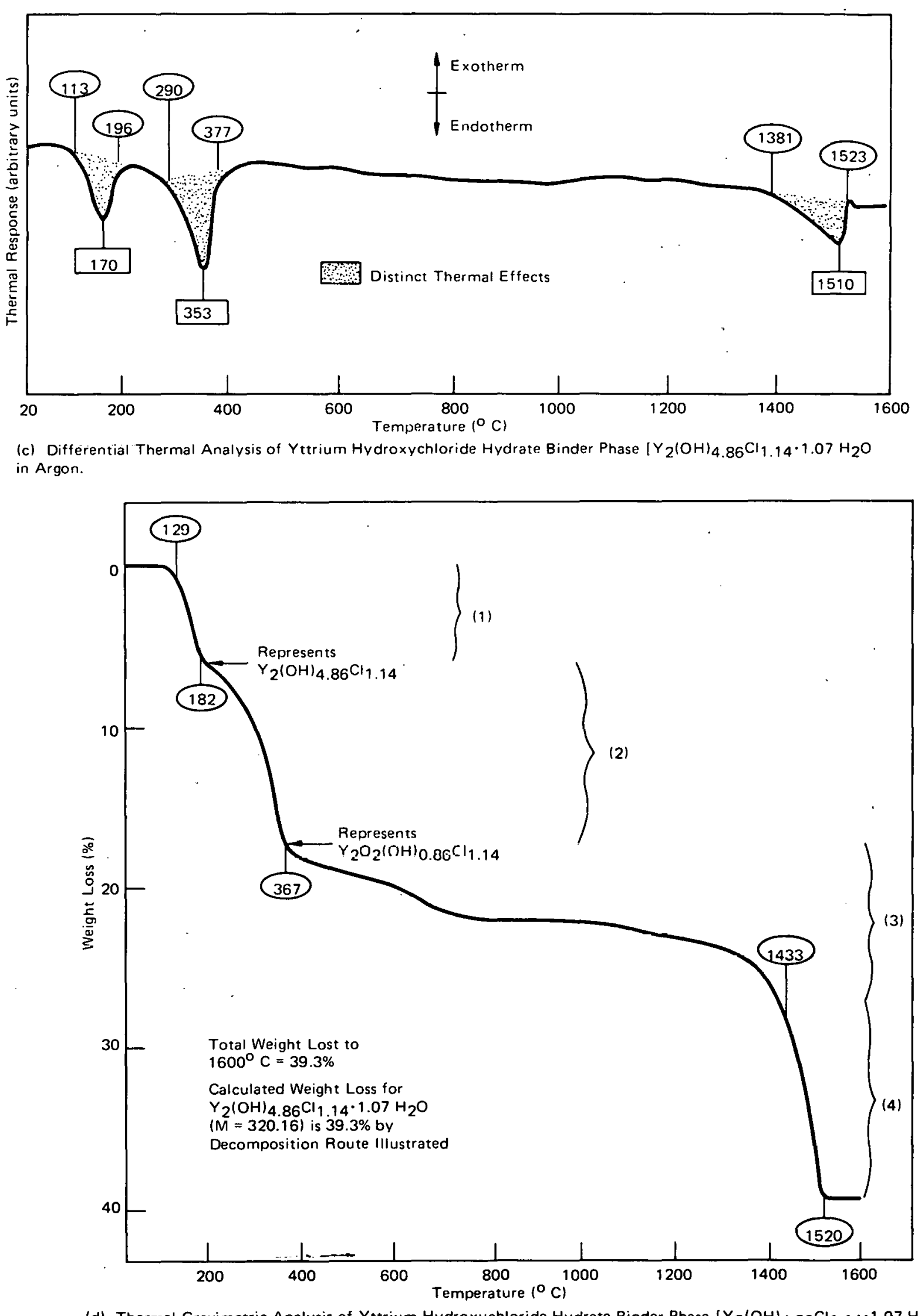

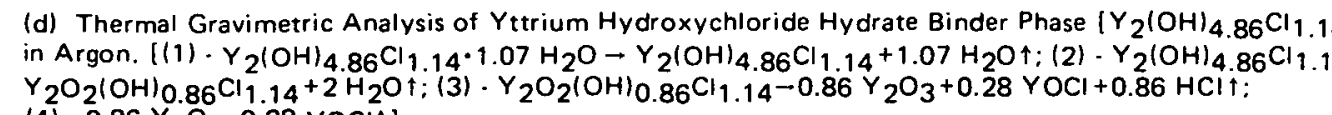

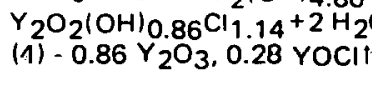
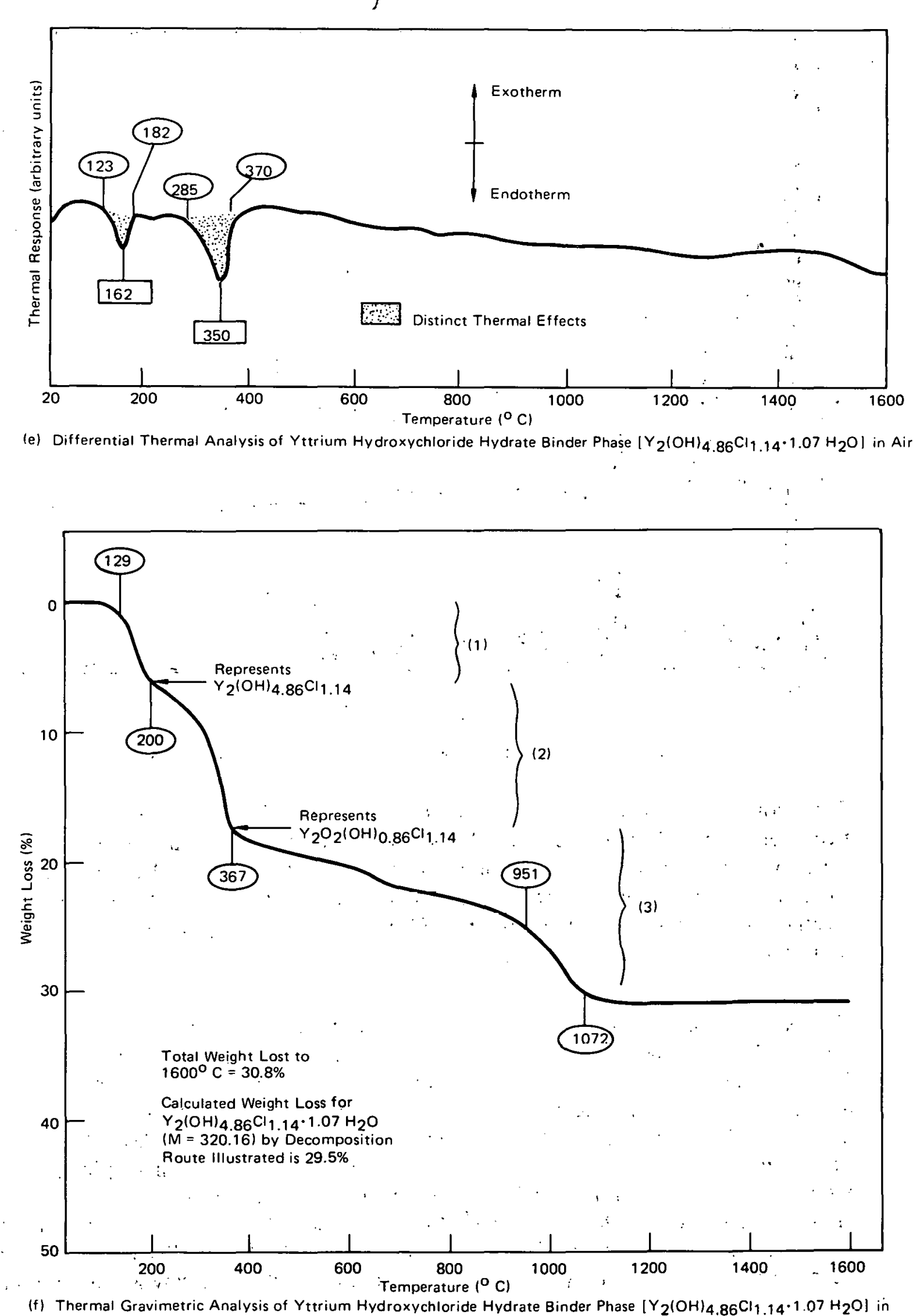

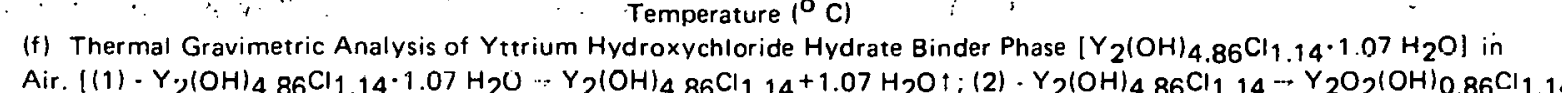

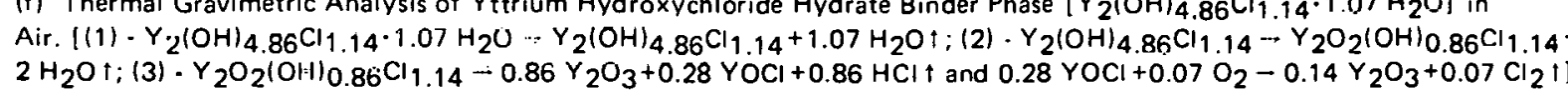


(giving near plateaus on the TGA curves) is thus common to both the precipitated and hydrothermally produced hydroxynitrate phases.

For chloride materials, TG-quad indicated that only water was evolved below $400^{\circ} \mathrm{C}$; hydrochloric acid was the only other species detected (above $400^{\circ} \mathrm{C}$ ). Initially, thermal analyses in argon to $1000^{\circ} \mathrm{C}$ showed that the chloride phases were not completely decomposed. A residue examined by XRD after a $1000^{\circ} \mathrm{C}$ heating in argon revealed only yttria and an unidentified material (diffraction peaks at 9.4, 4.7, 3.2 and $2.87 \AA$; the first peak was of medium intensity and the latter three were weak on Debye-Scherrer film). Thermal analyses in argon were extended to $1600^{\circ} \mathrm{C}$ (as indicated in Graphs $\mathrm{c}$ and d, Figure $3)$, where the endotherm beginning at $1381^{\circ} \mathrm{C}$ is the only thermal effect not caused by dehydration. Examination of the residue by $X R D$ and chlorine analyses showed that only yttria was present. The results may be explained by the decomposition route illustrated in Graph d, if the endothermal effect above $1381^{\circ} \mathrm{C}$ results from sublimation of yttrium oxychloride $\left(\mathrm{YOCl}\right.$ or some other complex phase such as $\mathrm{Y}_{3} \mathrm{O}_{4} \mathrm{Cl} 27$ ). No plateau region would occur at the yttrium oxychloride composition because of its rapid volatilization by $1430^{\circ} \mathrm{C}$. This decomposition route differs somewhat from that proposed by Lance and Haschke 22 for $\mathrm{La}_{2}(\mathrm{OH})_{5.1} \mathrm{Cl}_{0.9}$ in the region from 300 to $900^{\circ} \mathrm{C}$, since they accounted for their observations primarily by water evolution (instead of $\mathrm{HCl}$ ) to yield lanthanium oxychloride, La OCl.

Since the oxidation of yttrium oxychloride above $800^{\circ} \mathrm{C}$ had not been studied, thermal studies of the hydroxychloride binder phase were also undertaken in air, as reported in Graphs e and $f$ of Figure 3. It is apparent from Graph e that only the two endotherms from dehydration occur. The sublimation endotherm would not occur if yttrium oxychloride is not present; ie, from oxygen replacement of the chloride ions. This explanation also accounts for the weight-loss data in Graph $f$. The small deviation in the calculated and observed total weight losses by this route may be caused by some volatilization of yttrium oxychloride.

The reactivities of yttria plasters (both $\mathrm{HNO}_{3}$ and $\mathrm{HCl}$-produced plasters) were examined, using $7.9 \mathrm{M} . \mathrm{HNO}_{3}, 6.05 \mathrm{M} \mathrm{HCl}, 9.0 . \mathrm{M} \mathrm{H}_{2} \mathrm{SO}_{4}$, and $7.4 \underline{\mathrm{M} \mathrm{NH}} 4 \mathrm{OH}$. The plaster rapidly dissolved in these fairly concentrated nitric acid and hydrochloric acid solutions, but is essentially. insoluble in sulfuric acid and ammonium hydroxide solutions (1-hour observation). The minimal reactivity with sulfuric acid is somewhat surprising in view of the conclusion of Mzareulishvili15 that yttrium hydroxysulfates have a greater tendency to form than hydroxychlorides or hydroxynitrates.

\section{Possible Mechanism of Plaster Formation}

Since the "setting" behavior of yttria plaster is so similar to plaster of paris, a mechanism similar to that generally accepted for plaster of paris 1,2 may be applicable. By analogy, after a fluid slurry of the-dilute acid is created, a supersaturation of the liquid with yttrium hydroxysalt binder could occur, followed by precipitation of colloidal binder-phase particles that serve as nuclei for simultaneous deposition and growth of other, larger, binder-phase 
crystals. The heat evolution, which occurs a few minutes after mixing, is presumably from rapid dissolution and crystallization. It is possible. that the initial acid reaction causes dissolution of yttria (as $Y X_{3} \cdot n_{2} \mathrm{O}$, where $X$ represents $\mathrm{NO}_{3}^{-}$or $\mathrm{Cl}^{-}$, and $n \sim 6$ ), followed by reaction of the soluble salt with yttria to yield the amorphous, sparingly soluble hydroxysalt binder which crystallizes to eventually form the tangled network of randomly oriented, coherent crystals. Although no residual $\mathrm{Y} X_{3} \cdot \mathrm{nH}_{2} \mathrm{O}$ phase was detected by $X R D$ analysis, some could have been present below the detection limits.

Materials Incorporation into Yttria Plaster

For various applications, composites with yttria plaster might be required. Thus, several materials were mixed with yttria powder and treated with dilute nitric acid in the same manner as pure yttria.

Oxide additives (nominally $>99$ wt \% pure) included those listed in Table 4. These plasters were prepared with $2.63 \underline{\mathrm{M}} \mathrm{HNO}_{3}$ solutions. Also, niobium metal powder [- 400 mesh (or $-37 \mu \mathrm{m})]$ could readily be incorporated into the yttria plaster. Several concentrations were used, namely: from 10 to $25 \mathrm{wt} \% \mathrm{Nb}$, with L/P ratios from 0.3 to 0.8 using a $1.76 \underline{\mathrm{M}} \mathrm{HNO}_{3}$ solution.

\section{Yttria Plaster Sinterability Studies}

Because of the reticulated structure of yttria plaster and its easy formability, it was considered an ideal candidate for castable, porous refractory insulation. The previously mentioned thermal analyses indicated the encouraging results that the weight loss was gradual. Initial sintering tests with nitric acid-produced plaster in argon used heating rates from 100 to $200^{\circ} \mathrm{C}$ per hour in the critical region (room temperature to $600^{\circ} \mathrm{C}$, the region where maximum evolution of volatiles occurs), with rates from 250 to $500^{\circ} \mathrm{C}$ per hour above $600^{\circ} \mathrm{C}$. These rates were adequate for thin $(<0.6 \mathrm{~cm})$ specimens. The hydrochloric acid-produced plaster, when sintered to $1350^{\circ} \mathrm{C}$ in argon, was very friable and exhibited almost no shrinkage. Delayed sublimation of yttrium oxychloride appears to inhibit sintering in argon. Since nitric acid-produced plasters were not friable when sintered to $1350^{\circ} \mathrm{C}$ in argon, they were further tested. The data are presented in Table 5 . The change in microstructure on sintering the $\mathrm{HNO}_{3}$-produced plaster is shown in Figure 4 and may be compared to Figure 1 (starting yttria plaster). Thus, the cotton-appearing matrix disappears, with only the needles and plates remaining up to $1350^{\circ} \mathrm{C}$, after which the yttria tends to become equiaxed gräins.

Sintering of parts thicker than $0.6 \mathrm{~cm}$ required a much slower heating rate in the critical region. For a crack-free, 1.3 -cm-thick sample of nitric acid-produced plaster, a $10^{\circ} \mathrm{C}$-per-hour rate was used to $600^{\circ} \mathrm{C}$, followed with a rate of $50^{\circ} \mathrm{C}$ per hour to $1350^{\circ} \mathrm{C}$ (a one-hour 


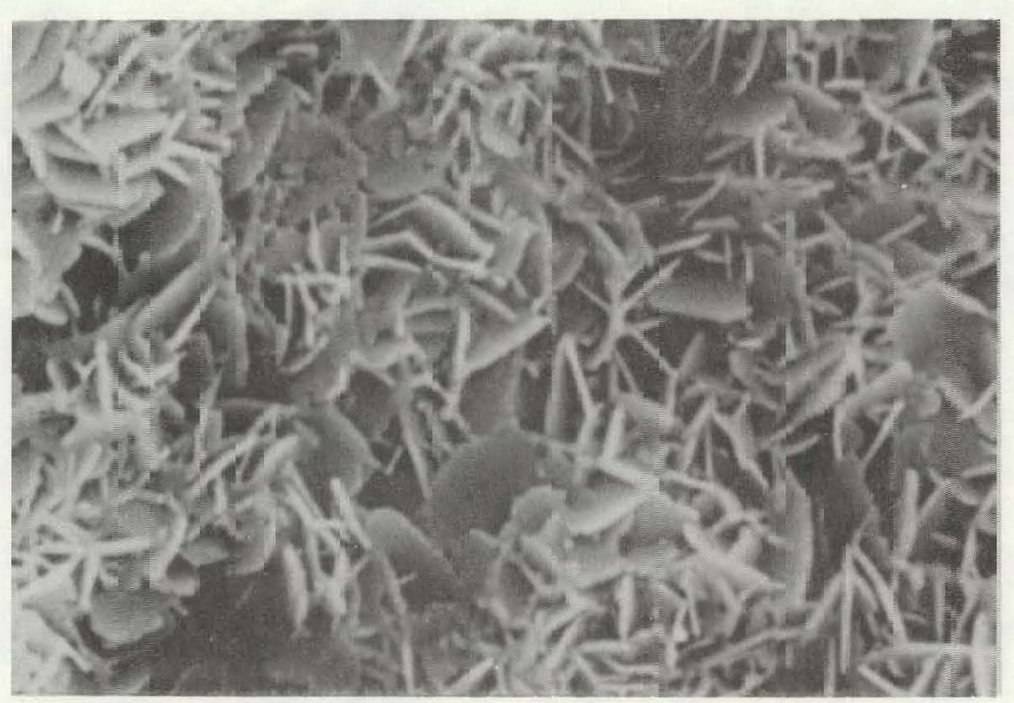

(a) At $1100^{\circ} \mathrm{C}$.

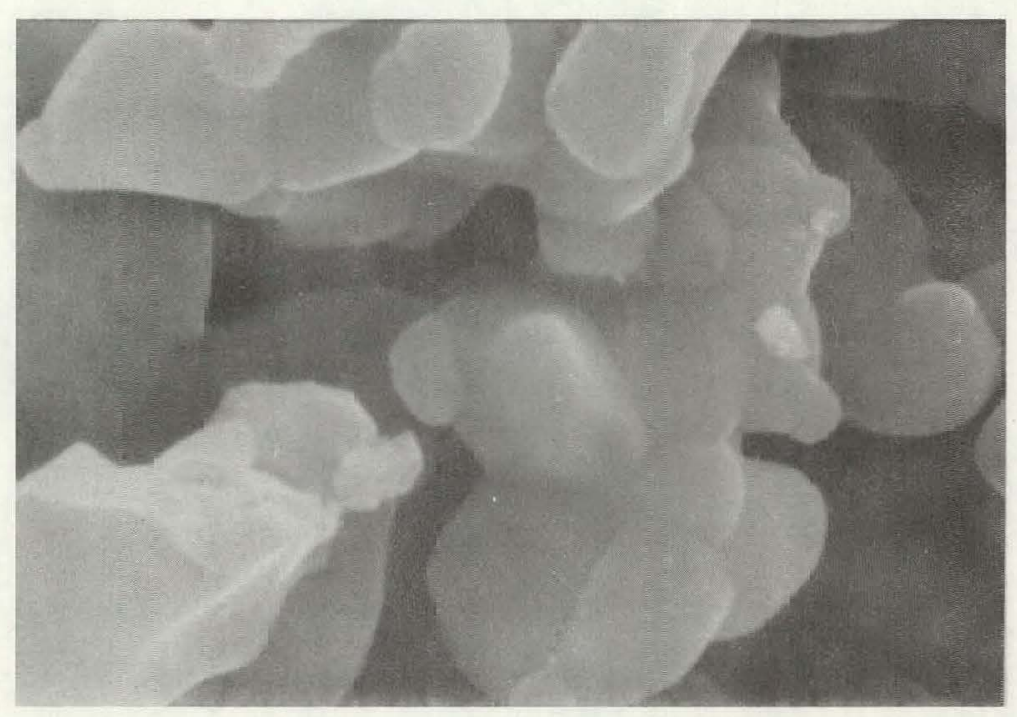

(c) At ${ }^{\circ} 6000 \mathrm{c}$

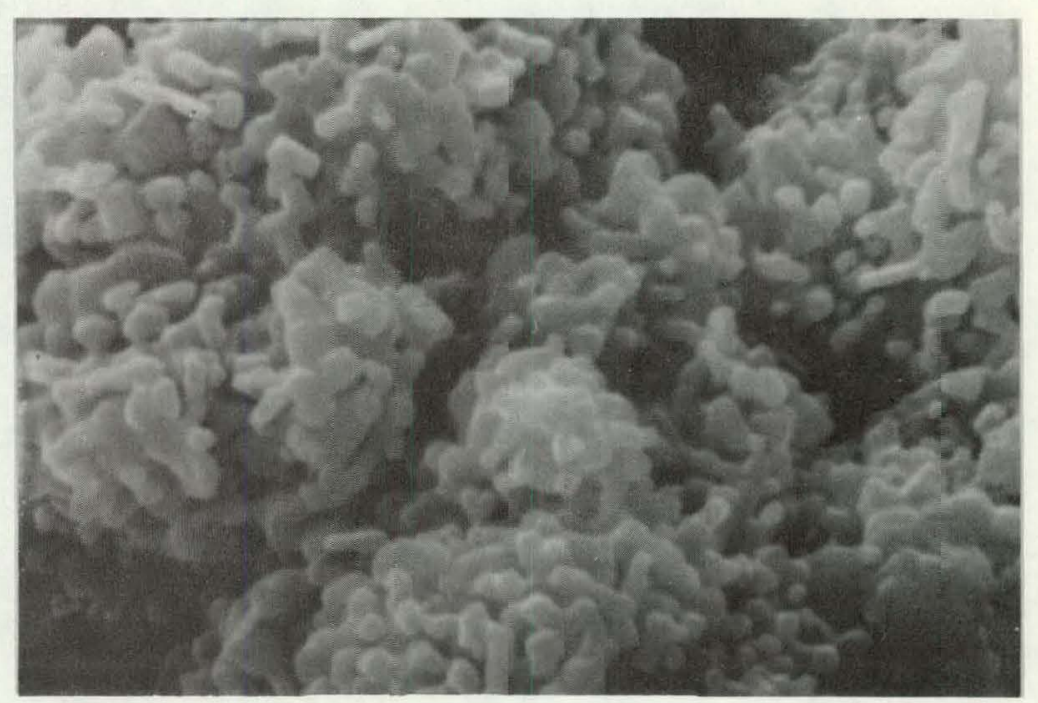

(b) At $1350^{\circ} \mathrm{C}$.

Figure 4. CHANGE IN THE MICRGSTRUCTURE OF SINTERED YTTRIA PLASTER. (SEM Morphology) 
Table 5

CHARACTERIZATION OF SINTERED YTTRPA PLASTER

\begin{tabular}{|c|c|c|c|c|c|c|c|c|}
\hline \multirow[b]{2}{*}{ Condition } & \multicolumn{6}{|c|}{ Determined by Mercury Intrusion Porosimeter } & \multirow[b]{2}{*}{$\begin{array}{c}\text { Linear } \\
\text { Shrinkage } \\
(\%)\end{array}$} & \\
\hline & $\begin{array}{c}\text { Bulk } \\
\text { Density } \\
\left(\mathrm{g} / \mathrm{cm}^{3}\right)\end{array}$ & $\begin{array}{l}\text { Apparent } \\
\text { Specific } \\
\text { Gravity (1) }\end{array}$ & $\begin{array}{c}\text { Porosity } \\
\text { (\%) }\end{array}$ & $\begin{array}{c}\text { Surface } \\
\text { Area } \\
\left(\mathrm{m}^{2} / \mathrm{g}\right)\end{array}$ & $\begin{array}{l}\text { Average } \\
\text { Pore } \\
\text { Diameter } \\
(\mu \mathrm{m})\end{array}$ & $\begin{array}{c}\text { Percentage } \\
\text { of Pores } \\
<10 \mu \mathrm{m} \text { in } \\
\text { Diameter }\end{array}$ & & \\
\hline $\begin{array}{l}\text { Starting } \\
\text { Plaster (2) }\end{array}$ & 1.13 & 2.68 & 57.8 & 11.8 & 1.9 & 100.0 & - & \multirow{4}{*}{$\begin{array}{l}\text { Holding } \\
\text { Period of } \\
\text { One Hour }\end{array}$} \\
\hline $\begin{array}{l}\text { Sintered at } \\
1100^{\circ} \mathrm{C}\end{array}$ & 1.61 & 5.37 & 70.1 & 9.8 & 2.6 & 97.3 & 21 & \\
\hline $\begin{array}{l}\text { Sintered at } \\
1350^{\circ} \mathrm{C}\end{array}$ & 2.11 & 5.08 & 58.5 & 1.1 & 3.1 & 95.7 & 25 & \\
\hline $\begin{array}{l}\text { Sintered at } \\
1600^{\circ} \mathrm{C}\end{array}$ & 2.35 & 4.83 & 51.3 & 0.3 & 3.7 & 98.2 & 33 & \\
\hline
\end{tabular}

(1) Theoretical (X-ray) density of $\mathrm{Y}_{2} \mathrm{O}_{3}$ is $5.03 \mathrm{~g} / \mathrm{cm}^{3}$.

(2) L/P ratio 1.44 , using $3.16 \underline{\mathrm{M}} \mathrm{HNO}_{3}$.

holding period). A TGA study, with a comparably slow heating rate $\left(30^{\circ} \mathrm{C} / \mathrm{hr}\right)$ showed that a very uniform rate of evolution of volatiles resulted under these conditions.

Thus, parts that are $1.3 \mathrm{~cm}$ in thickness may be sintered, which would be adequate for most uses. If thicker sections are required (ie, for insulation), several thinner sections could be used additively.

\section{Analogous Rare-Earth-Oxide Plasters}

Using dilute nitric acid $(1.44 \underline{M} ; L / P=1.0)$ and freshly calcined $\left(600^{\circ} \mathrm{C}\right.$ in air) powders, tests showed that several rare-earth oxides $\left(\mathrm{Eu}_{2} \mathrm{O}_{3}, \mathrm{Gd}_{2} \mathrm{O}_{3}, \mathrm{Nd}_{2} \mathrm{O}_{3}\right.$, and $\left.\mathrm{Sm}_{2} \mathrm{O}_{3}\right)$ formed plasters, with the latter two having less strength. With dilute hydrochloric acid (1.1 $\underline{\mathrm{M}}$; $L / P=1.0)$ and freshly calcined powders, four other rare-earth oxides ( $\mathrm{TbO}_{1.8}-2.0$, $\mathrm{Tm}_{2} \mathrm{O}_{3}, \mathrm{Yb}_{2} \mathrm{O}_{3}$, and $\mathrm{Lu}_{2} \mathrm{O}_{3}$ ) formed plasters, with the latter three having less strength. Although these studies showed that not all rare-earth oxides (or scandium oxide) form plasters, their hydroxysalts (nitrate or chloride) may exist and might be prepared by precipitation, as with yttrium hydroxysalts. The fact that only a few of the rare-earth oxides form plasters may result from kinetic and/or solubility relationships with the hydroxysalts, restricting the formation of interlocking needles or plates.

The europia and gadolinia plasters may be of interest (in the unsintered state) as readily formable neutron-shielding materials.

\section{CONCLUSIONS}

A new plaster can be formed by simple reactions of yttria powder with the common acids, rapidly setting into a rigid body consisting of a hydroxysalt binder phase and unreacted 
yttria. Resulting plaster bodies can be dried and sintered to form refractory, porous yttria insulation which would be inert to many reactive materials. 


\section{REFERENCES}

1. Schiller, K.; "Mechanism of Recrystallization in Calcium Sulphate Hemihydrate Plasters", J Appl Chem (London), 12, (3), pp 135 - 144 (1962).

2. Taplin, J. H.; "Kinetic Models for the Setting of Plaster of Paris", J Appl Chem Biotechnol (London), 23, pp 349 - 355 (1973).

3. Ridge, M. J. and Surkevicius, H.; "Hydration of Calcium Sulphate Hemihydrate, I. Kinetics of the Reaction", J App/ Chem (London), 12, (6), pp 246 - 252 (1962).

4. Ridge, M. J. and King, G. A.; "Comments on Use of Reduced Time in Plotting Kinetic Data", J Amer Ceram Soc, 55, (2), pp 112 - 113 (1972).

5. Jacobs, S.; "Hydration of Calcium Sulphate Hemihydrate", Nature 204, pp $70-71$ (1964).

6. Lambe, C. M. and Offutt, J. S.; "Consistency Classification of Industrial Plasters", Amer Ceram Soc Bull, 33, (9), pp 272 - 276 (1964).

7. Sychev, M. M.; "Classification of Binding Materials, I", J Appl Chem of the USSR (Russian translation), 43, (3), pp 536 - 540 (1968).

8. Sychev, M. M.; "Classification of Binding Materials, II", J App/ Chem of the USSR (Russian translation), 43, (4), pp 765 - 768 (1968).

9. Kingery, W. D.; "Fundamental Study of Phnsphate Ronding in Refractorios: I, Literature Review", J Amer Ceram Soc, 33, (8), pp 239 - 241 (1950).

10. Kingery, W. D.; "II, Cold-Setting Properties", J Amer Ceram Soc, 33, (8), pp 242 - 247 (1950).

11. Federov, N. F.; "Cements Based on Systems of the Metal Oxide-Acid Type", J Appl Chem of the USSR (Russian translation), 41, (12), pp 2591 - 2592 (1966).

12. Klug, H. P. and Alexander, L. E.; X-Ray Diffraction Procedures, pp $410-439$, John Wiley \& Sons, New York (1954).

13. Chung, F. H.; "A New X-Ray Diffraction Method for Quantitative Multicomponent Analysis", in Advances in X-Ray Analysis, 17, pp $106-115$, Edited by C. L. Grant, C. S. Barrett, J. B. Newkirk, and C. O. Ruud; Plenum Press, New York (1975).

14. Drake, L. C. and Ritter, H. L.; "Macropore-Size Distributions in Some Typical Porous Substances", Ind Eng Chem, 17, (12), pp 787 - 791 (1945). 
15. Mzareulishvili, N. V.; "Formation of Hydroxide and Basic Salts of Yttrium", Kompleksnye Soedineniya Nekotrykh Perekhodnykh i Redkikh Elementov (Complex Compounds of Transition and Rare Metals), pp 47 - 58 (1966) (In Russian).

16. Mal'kevich, N. V. and Grishin, I. A.; "Properties of Yttrium and Scandium Basic Salts", Ucheyne Zapiski Gorkovskogo Gosudarstvennogo Universiteta, (105), pp 34:38 (1970) (In Russian).

17. Polyshov, I. M., Mal'kevich, N. V., and Grishin, I. A.; "Formation of Yttrium Hydroxide", Trudy Gor'kovskogo Politekhnicheskogo Instituta, 29, (3), pp $55-60$ (1973) (In Russian).

18. Korenman, I. M. and Novikova, A. M.; "The Reaction of Yttrium Salts with Alkalies", Trudy po Khimi i Khimicheskoi Tekhnologii, (1). pp 41 - 44 (1962) (In Russian).

19. Mal'kevich, N. V. and Mironov, N. N.; "Thermal Analysis of some Basic Scandium and Yttrium Salts", Trudy po Khimi i Khimicheskoi Tekhnologii, (2), pp $10-12$ (1970) (In Russian).

20. Haschke. J. M.: "Preparation, Phase Equilibria, Crystal Chemistry, and Some Properties of Lanthanide Hydroxide Nitrates", Inorg Chem, 13, (8), pp 1812 - 1818 (1974).

21. Haschke, J. M.; "Structural Relationships, Crystal Chemistry and Anion Substitution Processes for $M(111) X_{3}$ Systems of the Lanthanides and Actinides", J Solid State Chem, 14, pp $238-246$ (1975).

22. Lance, E. T. and Haschke, J. M.; "Preparation, Phase Equilibria, and Crystal Chemistry of Lanthanum, Praseodymium, and Neodymium Hydroxide Chlorides", J Solid State Chem, 17, pp 55 - 60 (1976).

23. Haschke, J. M.; Personal Communication of XRD Data Submitted to Joint Committee on Powder Diffraction Standards (1976).

24. Klevtsov, P. V., Klevtsova, R. F., and Sheina, L. P.; "Cryslälline Yttrium Hydroxychloride", J Struct Chem (Russian translation), 6, (5), pp 449 - 451 (1965).

25. Klevtsova, R. F., and Klevtsov, P. V.; "X-Ray Diffraction Study of a New Modification of Yttrium Hydroxychloride $\mathrm{Y}(\mathrm{OH})_{2} \mathrm{Cl}^{\prime \prime}$, J Struct Chem, 7, (1), pp $524-527$ (1966).

26. Dornberger-Schiff, K. and Klevtsova, R. F.; "On the Relation Between the Monoclinic and the Orthorhombic Form of Yttrium Hydroxychloride", Acta Cryst, 22, pp 435 - 436 (1967).

27. Natansohn, S.; "Yttrium Tetraoxychloride $\mathrm{Y}_{3} \mathrm{O}_{4} \mathrm{Cl}^{\prime}$, J Inorg Nucl Chem, 30, pp 3123 - 3124 (1968). 


\section{ACKNOWLEDGEMENTS}

The authors: wish to : take this opportunity to thank R. L. Swain of the ORNL and J. G. Banker of Y-12 Development for their participation in the discovery of this material during a crucible-coating screening study. Appreciation is also extended to personnel of the Y-12 Plant Laboratory and the Analytical Development Department for their.participation in the material analyses. 


\section{Distribution}

Air Force Materials Laboratory - Wright Patterson

Mazdiyasni, K. S.

Department of Energy - Albuquerque

Vespe, V. C.

Department of Energy - DMA-Washington

Hagedorn, Z., Lt Col

Department of Energy - Oak Ridge

Hickman, H. D:

Leed, R. E.

Zachry, D. S., Ji

Joint Committee on Powder Diffraction

Standards - Swarthmore

Lawrence Livermore Laboratory

Broadman, G. A./Hanson, E. R.

Crowley, W. B.

Gamble, D. P.

Hodges, A. J./Price, P. N.

Hoenig, C.

Kane, J. S:

Nelson, W. E.

Otsuki, H. H.

Reynolds, H. L./Kury, J. H.

Rizzo, H. F. Wilson, H. D.

Technical Information Division

\section{Los Alamos Scientific Laboratory}

Baker, R. D.

Byers, $D$.

Deinken, H.P.

Eyster, E. H.

Fuller, J. C.

Gac, F.

Horpedahl, L.

Hoyt, H. C.

Library Services

Olwin, R. B.

Plassmanin, E. H.

Shafer, B. P.

Shreffler, R. G.

Skaggs, S. R.

Stoddard, S. D.

Taub, J. M.

Taylor, J.

Wechsler, J. J. .
Oak Ridge Gaseous Diffusion Plant

Steif, S. S.

Wilcox, W. J., Jr

Oak Ridge National Laboratory

Weir, J. R., Jr

Oak Ridge Y-12 Plant

Alvey, H. E.

Armstrong, R. C.

Briscoe, O.W.

Burditt, H. B.

Carpenter, D. A. (5)

Condon, J. B.

Dodson, W. H.

Duerksen, W. K.

Duggan, H. G.

Edwards, C. C. (5)

Fraser, R. J.

Gritzner, V. B.

Holcombe, C. E. (15)

Hovis, V. M.

Hulsey, W. J.

Jones, F. W.

Kahl, K. G.

Keith, A.

Kite, H. T.

Long, P. J.

Marrow, G. B.

Martin, W. R./Googin, J. M.

Mason, D. L./Schreyer, J. M.

McLendon, J. D.

Mills, J. M., Jr

Phillips, L. R.

Rhew, J. E.

Rice, R. N.

Smith, H. F., Jr

Smith, J. H.

Smith, R. D.

Smith, W. E.

Snyder, W. B.

Stoner, H. H.

Tewes, W. E.

Thompson, W. H., Jr

Townsend, A. B.

Weber, G. W.

Williams, R. D.

Y-12 Central Files (10)

$Y-12$ Central Files (master copy)

$Y$-12 Central Files (route copy)

$Y$ ' 12 Central Files $(Y-12 R C)$ 


\section{Paducah Gaseous Diffusion Plant}

Bewley, H. D.

\section{Pennsylvania State University}

Bradt, R. C.

\section{Sandia - Albuquerque}

Berry, L. M.

Bild, C. F.

Braasch, R. H.

Chabai, A. J.

Gardner, W. A.

Heilman, L. J.

Lang, J. J.

Mail Service Section

McDonald, J. E.

Peurifoy, R. L., Jr

Schuster, D. M.

Shuster, D. B:

Stroller, H. M.

\section{Sandia - Livermore}

Adolphson, D. R.

Barham, J. F.

Baroody, R. A.

Brandvold, G. E.

Brierly, J. M.

Gilson, J.

Gregson, D. E.

Kina. J. C.

Marion, J. E.

Meinken, R. $\mathrm{H}$.

Technical Library

Union Carbide Corporation - New York

Chambers, W. E.

Winters, $\mathrm{C}$.

\section{University of Tennessee - College}

of Engineering

Stansbury, E. E. 